
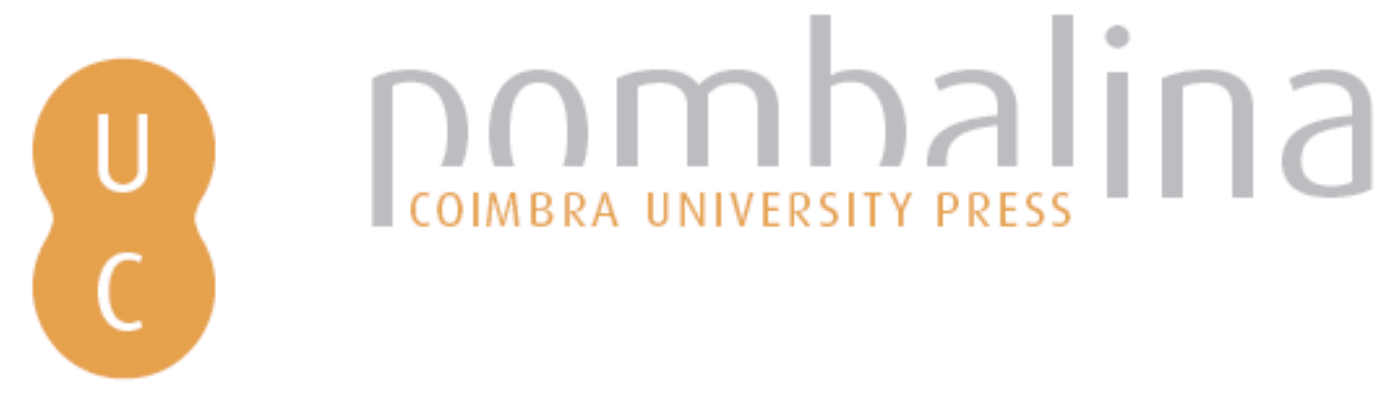

\title{
Validation of burn scar mapping: Pilot case in Peloponnesus, Greece
}

Autor(es): $\quad$ Eftychidis, G.; Leventakis, G.; Hirn, B.; Ferrucci, F.; Laneve, G.

Publicado por: Imprensa da Universidade de Coimbra

URL

persistente: $\quad$ URI:http://hdl.handle.net/10316.2/34082

DOI: $\quad$ DOI:http://dx.doi.org/10.14195/978-989-26-0884-6_196

Accessed : $\quad$ 26-Apr-2023 11:46:58

A navegação consulta e descarregamento dos títulos inseridos nas Bibliotecas Digitais UC Digitalis, UC Pombalina e UC Impactum, pressupõem a aceitação plena e sem reservas dos Termos e Condições de Uso destas Bibliotecas Digitais, disponíveis em https://digitalis.uc.pt/pt-pt/termos.

Conforme exposto nos referidos Termos e Condições de Uso, o descarregamento de títulos de acesso restrito requer uma licença válida de autorização devendo o utilizador aceder ao(s) documento(s) a partir de um endereço de IP da instituição detentora da supramencionada licença.

Ao utilizador é apenas permitido o descarregamento para uso pessoal, pelo que o emprego do(s) título(s) descarregado(s) para outro fim, designadamente comercial, carece de autorização do respetivo autor ou editor da obra.

Na medida em que todas as obras da UC Digitalis se encontram protegidas pelo Código do Direito de Autor e Direitos Conexos e demais legislação aplicável, toda a cópia, parcial ou total, deste documento, nos casos em que é legalmente admitida, deverá conter ou fazer-se acompanhar por este aviso.

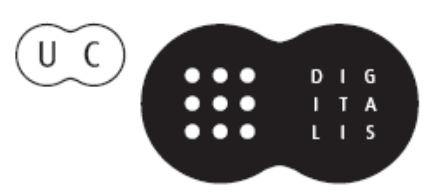




\section{ADVANCES IN}

Forest Fire

\section{RESEARCH}

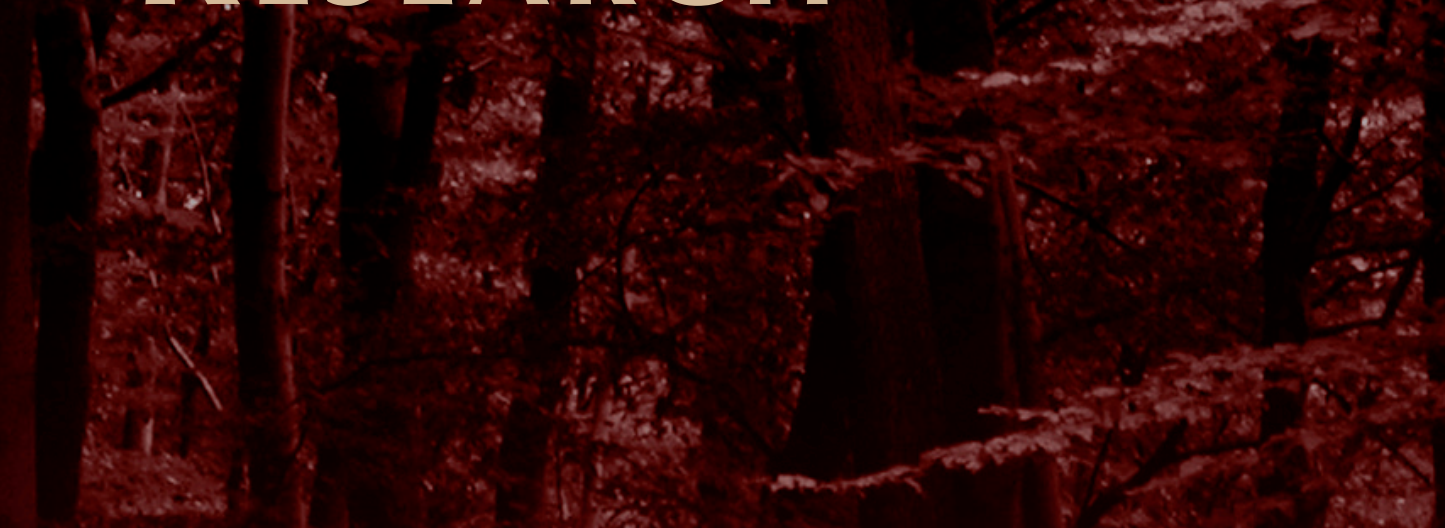

\section{DOMINGOS XAVIER VIEGAS}

\section{EDITOR}




\title{
Trends and changes of fire danger in Italy and its relationships with fire activity (1985-2008)
}

\author{
Valentina Bacciu ${ }^{\mathrm{a}, \mathrm{b}}$, Francesco Masala ${ }^{\mathrm{b}}$, Donatella Spano ${ }^{\mathrm{b}, \mathrm{a}}$, Costantino Sirca $^{\mathrm{b}, \mathrm{a}}$ \\ ${ }^{a}$ CMCC, Euro-Mediterranean Center on Climate Change, IAFENT Division, via E. de Nicola 9 \\ (Sassari), valentina.bacciu@cmcc.it \\ ${ }^{b}$ DipNeT, Dipartimento di Scienze della Natura e del Territorio, University of Sassari, via E. de \\ Nicola9 (Sassari), cosirca@uniss.it
}

\begin{abstract}
The comprehensive understanding of trends in fire activity and associated drivers is crucial to anticipate future trends and regulate fire potential impacts, by means of efficient fire and fuel management strategies. A valuable tool to examine past changes on fire potential and danger across fire regions is represented by fire weather indexes. In this study, spanning from 1985 to 2008, recent trends and patterns of fire danger and the relationships between the Canadian Fire Weather Index (FWI) System components and fire activity were investigated across Italy. Although time series trend analysis revealed a statistically significant increase in temperature, no clear pattern of fire danger increase was unveiled, while the number of days with high fire danger level increased significantly, especially in central and southern Italy. Monthly fire activity was modeled using as explanatory variables FWI components and significant coefficient of determination were obtained. The applied statistical approach (multiple linear regression) explained a consistent part of the fire occurrence variance all year long $(\mathrm{p}<0.001)$, although relevant differences across Italy were found.
\end{abstract}

Keywords: fire danger indexes, percentile analysis, trend analysis

\section{Introduction}

According to the last Intergovernmental Panel on Climate Change (IPCC, 2014), observed climate trends showed a variation in temperature and rainfall over Europe. There are different degrees of confidence that future climate will show an increase in high temperature extremes (high confidence) and meteorological drought (medium confidence), but small or no changes in wind speed extremes (low confidence), with diverse patterns varying considerably within and between regions.

It is well known that extreme weather events, such as extended drought and heat waves, facilitate and promote forest fire activity in Southern Europe. For example, during the dry spells in 2005, 2007 and 2009 a high number of large wildfires were recorded in South European countries (Pereira et al., 2005; EEA, 2010c; Koutsias et al., 2013; Salis et al., 2013). Future fire risk is projected to increase in Southern Europe (Carvalho et al., 2011; Dury et al., 2011; Vilén and Fernandes, 2011; Lung et al., 2013), along with the occurrence of high fire danger days (Arca et al., 2012) and fire season length (Pellizzaro et al., 2010). In this framework, the analysis of past conditions and the factors that shaped fire pattern plays a crucial role for the comprehensive understanding of trends in fire activity, so as to anticipate future fire potential and changes (e.g., Carvalho et al., 2010; Zumbrunnen et al., 2011; Amatulli et al., 2013), and to assess the ecological effects of forest fires, thus reaping the benefits (Moreno and Chuvieco, 2012).

During the last decades, fire weather indexes were often used to examine past changes on fire potential and danger across fire regions (e.g. Camia et al., 2008; Carvalho et al., 2008; Mäkelä et al., 2012; Wastl et al., 2012). These systems, combining relevant weather variables into suitable indexes, are usually valuable tools to estimate potentially dangerous conditions, as fire intensity or large size fires, and to help forest fires services in effective prevention and response to forecasted danger. A clear comprehension of the relationships between these indexes and fire occurrence features, as well as their 
efficiency, is of paramount importance in the implementation of fire policies and management (Carvalho et al., 2008; Bedia et al., 2012). Furthermore, the identification of areas with high fire danger and risk under severe and extreme environmental conditions is of utmost importance to cope and regulate their potential impacts through fire and fuel management (e.g. Fernandes, 2009; Arca et al., 2009; Salis et al., 2012b). Moreover, fire danger measurements are very valuable for all fire-fighting services, as they enable minimizing the level of uncertainty by combining scientific knowledge and operational experience (Valese 2008; Taylor and Alexander 2006).

One of the most commonly used fire danger rating systems across the world is the Canadian Fire Weather Index System (FWI), developed by Van Wagner and Pickett (1987). FWI has been very effective not only in Canada, where it was developed, but also in the Mediterranean area, as demonstrated in literature (e.g., Viegas et al., 1999; 2001). An important comparative study assessing the performance of different danger indexes in Southern Europe has revealed that FWI is the fire danger index best correlated with fire occurrence in Spain, France, Italy and Southern Portugal (Viegas et al., 1999). Therefore, FWI is a reliable fire danger system also in dry Mediterranean vegetation and climate conditions, which are very different from Canadian conditions where FWI was designed. However, despite its successful application in recent studies in Mediterranean regions (Moriondo et al. 2006; Valese 2008; Carvalho et al. 2008), it is noticeable that the performance of FWI and its relationship with fire occurrence show different response patterns according to the area considered (Carvalho 2008).

In relation to this, few works are available in Italy. With the intention to fill this knowledge gap and thus contribute to the understanding of past fire danger conditions, the main goals of this study are to (i) investigate and characterize recent trends and patterns of weather and fire danger in Italy, and then to (ii) unravel the relationships among the Canadian Fire Weather Index (FWI) System components and both fire number and burned area.

\section{Methods}

\subsection{Study area and data collection}

The area under investigation is Italy, which covers an area of about $301,000 \mathrm{~km}^{2}$ comprising the bootshaped Italian Peninsula and a number of islands including the two largest of the Mediterranean sea, Sicily and Sardinia. The climate of Italy, according to Köppen-Geiger (1954) climate classification, can be distinguished into 7 broad climatic regions, from the Mediterranean climate (characteristic of all coastal areas excluding the North-East) with mild and wet winter and hot and dry summers, to the Tundra climate with mean temperature below $10^{\circ} \mathrm{C}$ all year long. According to the Corine Land Cover classification (CLC 2006; EEA, 2007), agriculture is the main land use in Italy, covering $51.8 \%$ of the territory, closely followed by forested areas (40.2\%). Artificial surfaces occupy about $5 \%$ of the territory.

National fire data were obtained for the period 1985-2008 from two sources of data, the European Fire Database (EFD) from the Joint Research Center (JRC) and the Sardinian Forestry Corp (CFVA, Corpo Forestale e di Vigilanza Ambientale della Regione Sardegna) database. The EFD is the largest repository of information on individual fire events in Europe (Camia et al., 2010). The database summarizes, on a monthly basis, the number of fire events and the total burned area of a given NUTS (Nomenclature of Territorial Units for Statistics) 3 unit (administrative level of province). A preliminary analysis of the EFD database revealed a data gap for Sardinia Region from 1985 up to 1997, so the CFVA fire daily database was used instead for the whole study period.

The weather data were obtained from the interpolated $(25 \times 25 \mathrm{~km})$ daily meteorological database developed in the framework of "Monitoring of Agriculture with Remote Sensing" (MARS) project. The database was created using different weather data sources such as direct observations from meteorological stations, and from remote sensing platforms. The dataset, comprising the time period 1985-2008, consists of daily value of air temperature, precipitation, wind speed, and vapour pressure. 
Since relative humidity data were not available in the MARS database, we estimated it from the air temperature, vapour pressure, and the dew point temperature (Snyder and Show, 1984).

Finally, fire and weather datasets were aggregated in a database at $25 \mathrm{~km}$ resolution grid and on a monthly basis using ArcGIS 9.3 C-ESRI.

\subsection{Fire danger indexes and statistical analyses}

Fire danger was calculated through the Canadian forest Fire Weather Index System (FWI), which provides a rating of fire danger through fuel moisture and fire behaviour potential (Van Wagner, 1987). The FWI is composed by 6 sub-codes, the first 3 rating fuel moisture content of the forest floor layers and the other 3 the potential fire behaviour. The Fine Fuel Moisture Code (FFMC) rates the moisture of litter and other dead fine fuels at the top of the surface fuel layer; Duff Moisture Code (DMC) embodies the moisture content of loosely compacted, decomposing organic matter weighing about 5 $\mathrm{kg} \mathrm{m}^{-2}$, when dried (this is an indicator of fuel consumption in moderate duff layers and medium-sized woody material (Carvalho 2010)); and the Drought Code (DC) represents the moisture content of the deep layer of compact organic matter.

As outlined above, the other 3 sub-codes estimate the potential fire behaviour, combining the previous fuel moisture codes and weather. The Initial Spread Index (ISI), obtained by the combination of wind and the FFMC component, assesses the rate of fire spread without the influence of variable quantities of fuel; the Build Up Index (BUI) combines DMC and DC components to represent the total fuel available for combustion; and the final Fire Weather Index (FWI) is the combination of ISI and BUI components and represents the intensity of fire spreading as a rate of energy output per unit of fire front length. As highlighted by Alexander (2008), each individual component of the FWI system is actually a fire danger index, revealing different aspects of fire danger that are difficult to synthesize into one single number.

Usually, the FWI system is computed by daily meteorological variables recorded at noon. In this study, FWI was computed using daily meteorological values from MARS database as proxy of instantaneous values at 12:00. After the FWI system calculation, the dataset comprised daily values for all the 565 cells derived from the MARS dataset and for the whole 24-year period.

To handle this amount of data, a preliminary hierarchical cluster analysis, based on the fire/weather dataset, was performed to identify homogeneous areas in terms of fire occurrence and climate (pyroclimatic areas) (Bacciu et al., 2014) (Erro! A origem da referência não foi encontrada.). The MannKendall non-parametric statistical test was thus applied to evaluate the existence of trends on fire danger components and weather data series. As commented by Wastl et al. (2012), a shift in fire danger might be induced by an increase of either absolute index values or number of days with elevated index values. We thus calculated the number of days, for each year and pyro-climatic area, exceeding the threshold of the FWI $95^{\text {th }}$ percentile of the whole time period. Then we proceeded with the MannKendall non-parametric statistical test over the past 24 years to investigate on the eventual increase of fire extreme days. Mann-Kendall test was performed using an Excel macro named MAKESENS created by Salmi et al. (2002).

Finally, historical fire activity was analysed in relation to monthly averages of FWI system components to understand the relationships among variables and to develop statistical models to be used to project fire activity in the near future. Separate analyses were carried out at cluster level and a classical stepwise Multiple Linear Regression analysis was applied for the period 1985-1999 (training dataset). The Multiple Linear Regression is one of the most common methods applied to analyse relationships between fire activity and fire danger/weather parameters (e.g. Carvalho et al., 2008; Camia and Amatulli, 2009; Bacciu et al., 2014). The stepwise approach combines entry and removal of regression terms, which were accepted or discharged as long as they meet significance criteria. The natural logarithm was used to normalise burned area and fire number for the normality requirement, as it is a common procedure followed in other modelling works (Carvalho et al., 2008; Amatulli et al., 2013). The 9-year period 2000-2008 was then used as external validation dataset. The performances 
of the model equations were evaluated using the $R^{2}$ coefficient of determination between estimated and measured values.

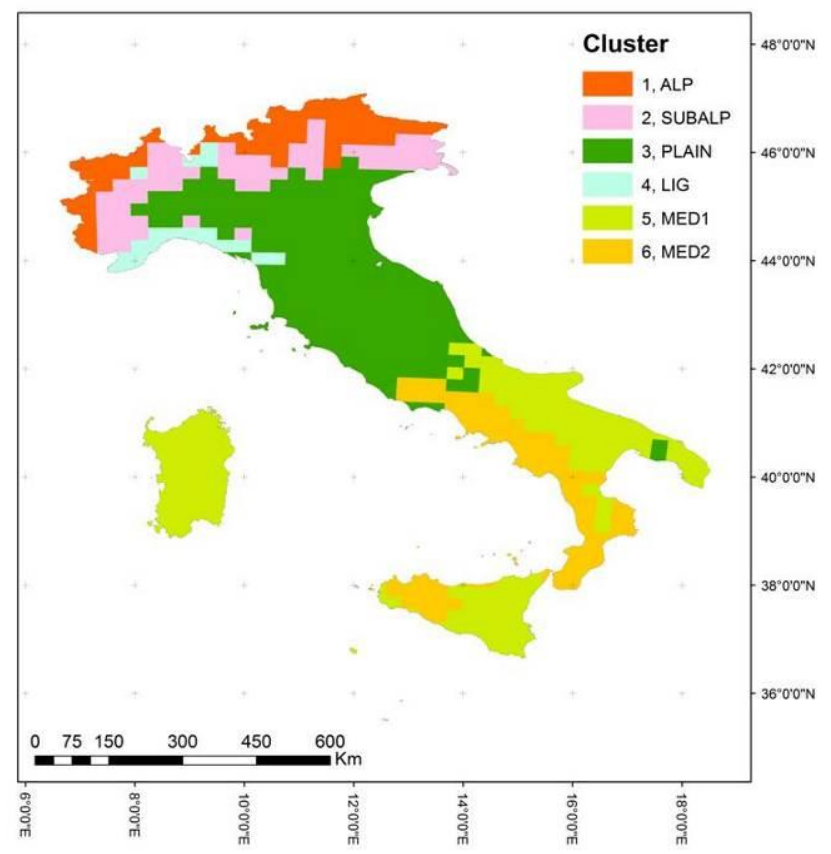

Figure 1. Map of pyro-climatic regions in Italy (from Bacciu et al., 2014)

\section{Results}

The descriptive statistic of the fire-regime metrics at cluster level is shown in Table 1. The most fireprone zones are located in the Southern clusters (MED1 and MED2) although a marked fire activity also occurred in LIG (19\% burned area over total, 2 fires $\mathrm{km}^{-2}$ ). From 1985 to 2008, about 2.5 million of hectares were burned ( $10 \%$ over the Italian total area), about 230,000 fire ignitions occurred, and the annual average burned area was $\sim 100,000$ ha. The maximum recorded area burned was in 1993 and 2007 (9.2\% and 9.1\% over the total, respectively). High level of inter-annual variability of burned area (computed through the coefficient of variation, cv) was found in Northern clusters (ALP and SUBALP) with low fire activity (0.2-0.4 fires $\mathrm{km}^{-2}$ ), suggesting a stronger influence by weather and climate. As expected, clusters with marked Mediterranean climate and significant fire activity (i.e. Sardinia, Calabria, and Sicily, which had the highest area burned values and number of occurrences in Italy) showed a low inter-annual variability in both fire number and burned area, probably due to persistent human activities.

Five-year averages of maximum and minimum temperatures as well as precipitation and relative humidity are displayed in Erro! A origem da referência não foi encontrada. for each pyro-climatic area. The Mann-Kendall trend test highlighted a generalized significant positive pattern for air temperature variables in all clusters (overall almost $0.5^{\circ} \mathrm{C}$ and $0.7^{\circ} \mathrm{C}$ per decade for maximum and minimum temperature, respectively). On the other hand, annual precipitation trends were not significant and the signs of the slopes were different across areas, while on the contrary relative humidity showed overall a significant negative pattern. 
Table 1. Number of fire (FN) and burned area (BA) statistics at cluster scales, for the period 1985-2008. CV is the coefficient of variation

\begin{tabular}{|c|c|c|c|c|c|c|c|c|c|}
\hline CLUSTER & CODE & $\begin{array}{c}\text { FN } \\
(* 1000)\end{array}$ & $\begin{array}{c}\text { BA } \\
\left(h a^{*} 1000\right)\end{array}$ & $\begin{array}{c}\% \\
\text { BURNED } \\
\text { OVER } \\
\text { TOTAL } \\
\end{array}$ & $\begin{array}{c}\text { FIRE } \\
\text { DENSITY } \\
\left(\mathrm{FN} \mathrm{km}^{-2}\right)\end{array}$ & $\begin{array}{l}\text { AVG FIRE } \\
\text { SIZE (ha) }\end{array}$ & CV FN & CV BA & $\begin{array}{c}\text { FIRE } \\
\text { SEASON } \\
\text { (Month) }\end{array}$ \\
\hline Cluster 1 & ALP & 6,2 & 62,0 & 1,99 & 0,20 & 9,97 & 0,49 & 1,22 & $12,1,2,3$ \\
\hline & SUBAL & & & & & & & & $12,1,2,3$ \\
\hline Cluster 2 & $\mathrm{P}$ & 13,8 & 147,5 & 4,27 & 0,40 & 10,66 & 0,46 & 1,20 & \\
\hline Cluster 3 & PLAIN & 37,2 & 279,1 & 2,62 & 0,35 & 7,50 & 0,47 & 0,77 & $\begin{array}{c}7,8,9 \\
12,1,2,3,\end{array}$ \\
\hline Cluster 4 & LIG & 21,4 & 193,9 & 19,00 & 2,10 & 9,06 & 0,52 & 0,76 & 8 \\
\hline Cluster 5 & MED1 & 89,8 & 1109,9 & 13,90 & 1,12 & 12,36 & 0,38 & 0,60 & $6,7,8,9$ \\
\hline Cluster 6 & MED2 & 64,4 & 669,4 & 16,90 & 1,63 & 10,40 & 0,41 & 0,66 & $6,7,8,9$ \\
\hline
\end{tabular}
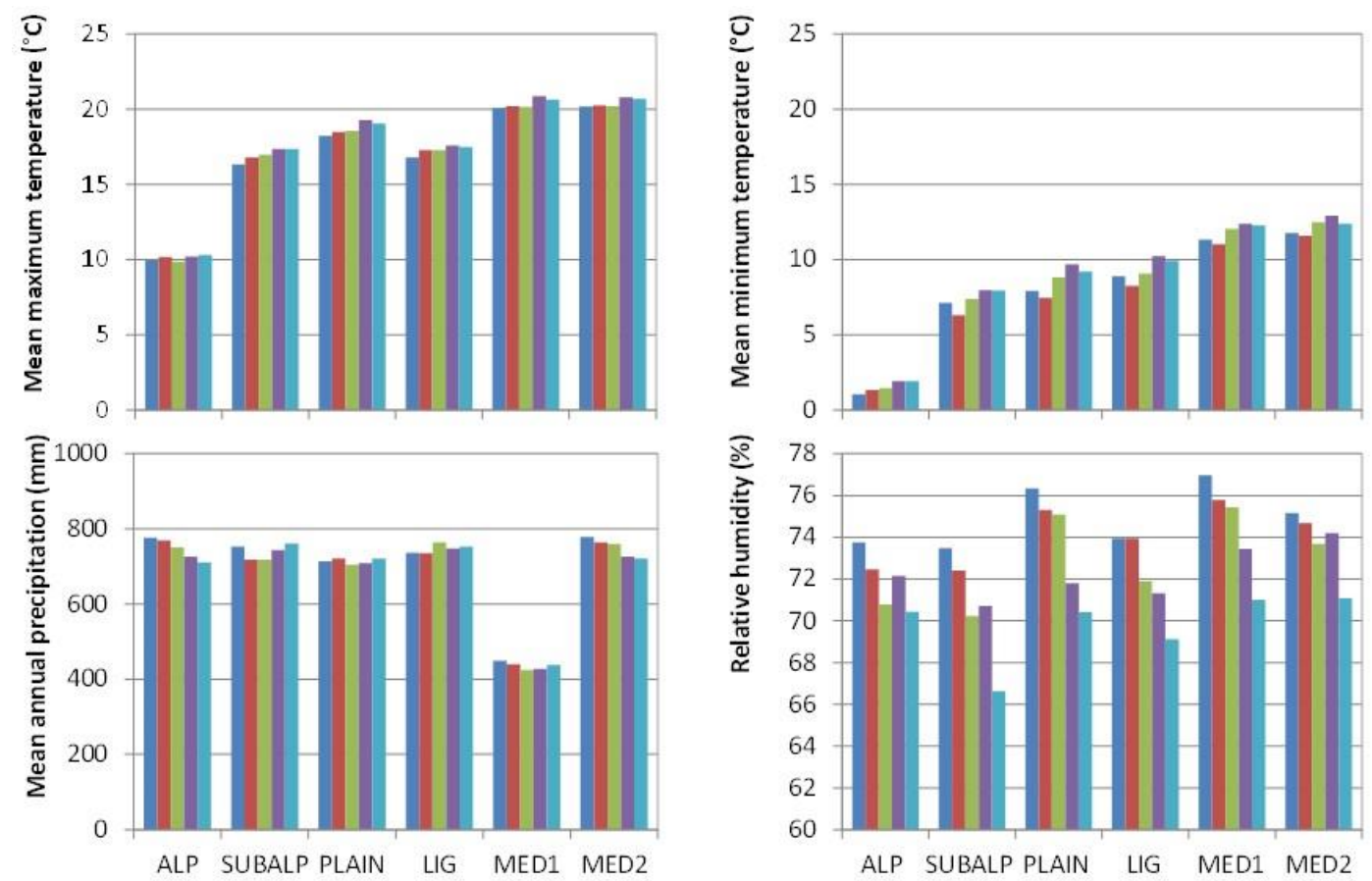

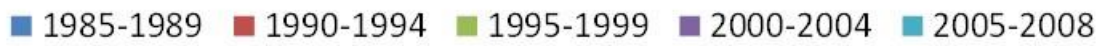

Figure 1. Evolution of mean maximum and minimum temperature, annual precipitation and relative humidity on a five-year basis (1985-1989, 1990-1994, 1995-1999, 2000-2004-2005-2008) in pyro-climatic areas

Overall, the statistical analysis of the mean forest fire danger index values (Erro! A origem da referência não foi encontrada.) revealed few significant changes during the 24 year of analysis. According to the Mann-Kendall trend test, there was a significant downward trend $(\mathrm{p}<0.01)$ in DC for ALP cluster, and a significant upward trend in four out to six cluster in ISI index. The number of days with exceptionally high meteorological fire danger was assessed calculating the annual number of days above the $95^{\text {th }}$ percentile threshold. The analysis showed overall a statistically significant increase during the analyzed period, ranging from 1 to 8 days per decade. Overall, the mean number of extreme fire danger days ranged from 4 in cluster ALP to 30 in cluster MED1. The most important increase in number of extreme fire danger days were recorded in PLAIN and MED1 clusters. Ranging from an average of 22 days in 1985-1996 to 39 days in the period 1997-2008, MED1 exhibited a significant 
increase of $43 \%$. A stronger increase $(65 \%)$ was recorded in SUBALP area, which went through an average of 7 days during the first period to 19 days in the period 1997-2008.

Table 2. Mann-Kendall trend test ( $Z$ score) results for mean FWI System components for each pyro-climatic area and mean annual number of days exceeding the FWI 95th percentile of the whole 24-year period.

\begin{tabular}{llllllllc}
\multicolumn{8}{c}{$* p=0.05 ; * * p=0.01 ; * * * p=0.001$} \\
\hline CLUSTER & FFMC & DC & DMC & ISI & BUI & FWI & $1985-1996$ & $1997-2008$ \\
\hline ALP & $-0,06$ & $-4,69 * *$ & $-0,21$ & 0,00 & $-0,39$ & $-0,03$ & 2 & 4 \\
SUBALP & 0,07 & $-3,29$ & 0,07 & $0,04 * *$ & $-0,08$ & 0,02 & 7 & 19 \\
PLAIN & 0,10 & 0,02 & 0,45 & $0,04 * *$ & 0,49 & 0,03 & 14 & 32 \\
LIG & 0,07 & 2,24 & 0,26 & $0,02 *$ & 0,43 & 0,03 & 9 & 24 \\
MED1 & 0,03 & $-3,83$ & 0,32 & $0,04 * *$ & 0,00 & 0,02 & 19 & 29 \\
MED2 & 0,08 & $-0,85$ & $-0,06$ & 0,01 & $-0,11$ & 0,02 & 22 & 39 \\
\hline
\end{tabular}

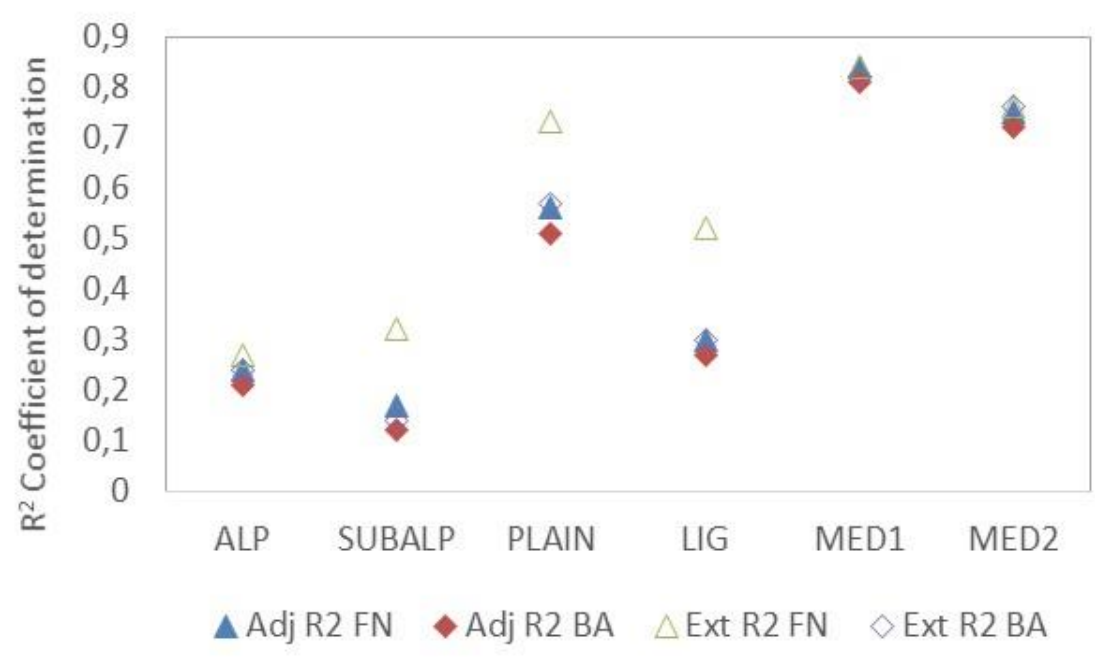

Figure 3. Monthly fire number and burned area explained variance (Adj $R^{2}$ ) and external validation values (Ext $\left.R^{2}\right)$

Coefficients of determination $\left(R^{2}\right)$ resulting from the Multiple Linear Regression analysis of monthly area burned and monthly number of fires considering the whole year for the six clusters across Italy are given in Figure 3. All coefficient were highly significant with $p<0.001$. We also checked for collinearity through the variance inflation factor (VIF). In those cases where predictors entered the final stepwise model and their VIF was higher than the value of 10, thus creating multicollinearity problems (Myers, 1990), we decided to exclude those variables from the regression in order to avoid any further inconsistencies. Finally, an informal analysis of the data using histograms and scatterplots was performed to reveal threats to the assumption of linearity of residuals of the dependent variable (data not shown).

The explained variance ranged from 17 to $84 \%$ for fire number and from 12 to $71 \%$ for burned area. Clusters in northern and central regions showed the lowest variances, accounting from $17 \%$ up to 56\% for fire number and from $12 \%$ to $51 \%$ for burned area in cluster SUBALP and in cluster PLAIN, respectively. On the other hand, pyro-climatic areas in southern regions exhibited variances above $70 \%$, for both fire number and burned area. The external validation $R^{2}$ values (period 2000-2008) are slightly bigger than the internal validation. 


\section{Discussion and conclusion}

In this study, we investigated recent trends in both climate and fire danger parameters and we highlighted the relationships between the FWI System components and fire activity in the 6 pyroclimatic areas identified by Bacciu et al. (2014).

As a first analysis, we applied the non parametric Mann-Kendall test to assess the statistical significance of weather and fire danger trends. The results of our study indicated the overall increase of temperatures, highlighting that the warming did not have homogeneous impacts all over the country, corroborating other findings over the past decades in Italy and in other areas of the Mediterranean Basin (e.g., Brunet et al., 2007; del Rio et al., 2012; Koutsias et al., 2012). Furthermore, annual precipitation records presented an unclear trend, except in the Alpine area. This data is consistent with the findings of Wastl et al. (2012), which reported for this area a slight increase of about $8 \%$ in annual precipitation. Moreover, our results highlighted a dichotomy in signs that seems to be in agreement with the results of other researchers.

Generally, the slope of the mean annual fire danger was positive at nearly every cluster, statistically significant in MED1. The situation in ALP cluster, as revealed by the weather variables, was the opposite with a statistically significant downward trend in mean values, probably influenced by the increase in total precipitation. The first results are in agreement with Moriondo et al. (2006), who found an increase in mean fire danger in the Mediterranean Basin. On the other hand, the clear decrease of the danger in ALP pyro-climatic area is in contrast with findings reported by Wastl et al. (2012) that showed a general increase of fire danger despite this trend was highly variable in consideration of the spatial and the time scale. The wide-ranging positive trend in fire danger corresponded also to a general increase in the frequency of extreme fire danger events. The analysis of the annual number of days above the $95^{\text {th }}$ percentile threshold showed that although southern clusters were characterized by a high number of extreme fire danger days, considerable increment occurred also in northern and central clusters.

Finally, by modelling both fire number and burned area on the basis of monthly FWI components in the different clusters, this study contributes to the understanding of the relationships between fire activity and fire danger indices. Although the study area presented a generalized decrease in both fire number and burned area for the period 1985-2005 (Spano et al., 2014; Bacciu et al., 2014), the multiple regression analysis showed that FWI system components (especially FFMC and ISI) are good predictors, especially for the clusters with summer fires. Similarly, Amatulli et al. (2013) highlighted the drought code (DC) and the initial spread index (ISI) as predictors consistently selected in the equations using the Multiple Linear Regression approach. Results achieved by Carvalho et al. (2008) in Portugal revealed that FWI mean and maximum values contributed to explain a great part of the variance in burned area.

Although fire activity in Italy is influenced by a number of factors not related, as fire danger, to weather conditions, the simple statistical models developed in this work can reproduce an important part of the inter-annual fire variability. Thus, the identified relationships could be incorporated in predictive models of fire risk and short- and long-term fire planning strategies that, in turn, could be boosted by the enhancement and a wider use of long-range climate outlooks (such as the seasonal and decadal predictions, e.g. Borrelli et al. (2012); Bellucci et al. (2014)). Furthermore, the developed models could be used as inputs for the construction of future fire scenarios (e.g., Amatulli et al., 2013) to understand the future magnitude of the issue and thus to develop new fire risk mitigation strategies.

\section{Acknowledgements}

The Authors would like to thank the JRC and Forest Service of Sardinia (CFVA) for providing fire occurrence data for this study. The researchers leading this work received funding from the Italian Ministry of Education, University and Research and the Italian Ministry of Environment, Land and 
Sea under the GEMINA project, from the OFIDIA Project "Operational FIre Danger preventIon plAtform" (European Territorial Cooperation Programme Greece-Italy 2007-2013), and from the PRIN CARBOTREES Project- "Climate change mitigation strategies in tree crops and forestry in Italy" (Prot. 201049EXTW).

\section{References}

Alexander ME (2008) Proposed revision of fire danger class criteria for forest and rural areas in New Zealand. Christchurch: National Rural Fire Authority, Wellington, in association with the Scion Rural Fire Research Group.

Amatulli G, Camia A, San-Miguel-Ayanz J (2013) Estimating future burned areas under changing climate in the EU-Mediterranean countries. Sci Total Environ 450-451:209-222

Arca B, Bacciu V, Pellizzaro G, Salis M, Ventura A, Duce P, Spano D, Brundu G (2009) Fuel Model Mapping by IKONOS Imagery to Support Spatially Explicit Fire Simulators. Proceedings of the 7th International Workshop on Advances in Remote Sensing and GIS Applications in Forest Fire Management towards an Operational Use of Remote Sensing in Forest Fire Management. Matera, Italy, 2-5 September 2009. ISBN: 978-88-904367-0-3.

Arca B, Salis M, Pellizzaro G, Bacciu V, Spano D, Duce P, Ager Aa, Finney MA (2010) Climate change impact on fire probability and severity in Mediterranean areas. In: Viegas D.X. (Ed.), VI International Forest Fire Research Conference, Coimbra, Portugal, electronic edition.

Bacciu V, Masala F, Salis M, Sirca C, SpanO D (2014) Analysis of weather conditions influencing fire regime in Italy. Geophysical Research Abstracts, vol. 16, ISSN: 1607-7962.

Bedia J, Herrera S, Gutierrez Jm, Zavala G. Urbieta Ir, Moreno Jm (2012) Sensitivity of fire weather index to different reanalysis products in the Iberian Peninsula, Nat. Hazards Earth Syst. Sci., 12, 699-708, doi:10.5194/nhess-12-699-2012.

Bellucci A, Haarsma R, Gualdi S, Athanasiadis Pj, Caian M, Cassou C, Fernandez E, Germe A, Jungclaus J, Kröger J, Matei D, Müller W, Pohlmann H, Salas Y Melia D, Sanchez E, Smith D, Terray L, Wyser K, Yang S (2014) An assessment of a multi-model ensemble of decadal climate predictions, Climate Dynamics, DOI 10.1007/s00382-014-2164-y

Borrelli A, Materia S, Bellucci A, Alessandri A, Gualdi S (2012) Seasonal Prediction System at CMCC. Research Papers Issue RP0147

Brunet M, Jones Pd, Sigro J, Saladie O, Aguilar E, Moberg A, Della-Marta Pm, Lister D, Walther A, Lopez D (2007) Temporal and spatial temperature variability and change over Spain during 1850 2005, J. Geophys. Res., 112, D12117, doi:10.1029/2006JD008249

Camia A, Durrant Houston T, San-Miguel J (2010) The European Fire Database: Development, Structure and Implementation In: Viegas D.X. (Ed.), Proc. VI International Conference on Forest Fire Research. Coimbra

Camia A, Amatulli G (2009) Weather Factors and Fire Danger in the Mediterranean. In: Chuvieco E, editor. Earth Observation of Wildland Fires in Mediterranean Ecosystems. Berlin: Springer-Verlag; 2009. p. 71-82. JRC55075

Camia A, Amatulli G, San-Miguel-Ayanz J (2008) Past and future trends in forest fire danger in Europe, JRC Scientific and Technical Reports, EUR 23427 EN, 7 pp., Ispra, Italy.

Carvalho A, Flannigan M, Logan K, Gowman L, Miranda Ai, Borrego C (2010) The impact of spatial resolution on area burned and fire occurrence projections in Portugal under climate change. Climatic Change 98, 177-197 DOI: 10.1007/s10584-009-9667-2

Carvalho A, Flannigan Md, Logan K, Miranda Ai, Borrego C (2008) Fire activity in Portugal and its relationship to weather and the Canadian Fire Weather Index System, Int. J. Wildland Fire, 17, 328 338. 
Carvalho Ac, Carvalho A, Martins H, Marques C, Rocha A, Borrego C, Viegas Dx, Miranda AI (2011) Fire weather risk assessment under climate change using a dynamical downscaling approach. Environmental Modelling \& Software, 26, 1123-1133.

Dury M, Hambuckers A, Warnant P, Henrot A, Favre E, Ouberdous M, François L (2011) Responses of European forest ecosystems to 21st century climate: assessing changes in interannual variability and fire intensity. iForest 4: 82-99

EEA (2007). European Environment Agency: CLC2006 Technical Guidelines. Copenhagen

EEA (2010c) The European environment - state and outlook 2010: assessment of global megatrends, European Environment Agency.

Del Rio S, Cano-Ortiz A, Herrero L, Penas A (2012) Recent trends in mean maximum and minimum air temperatures over Spain (1961-2006). Theor Appl Climatol 109:605-626. doi:10.1007/s00704012-0593-2

Fernandes PM (2009) Combining forest structure data and fuel modelling to classify fire hazard in Portugal. Annals of Forest Science 66 (4), 415-415

IPCC (2014) Climate Change 2014: Impacts, Adaptation, and Vulnerability. Part B: Regional Aspects. Contribution of Working Group II to the Fifth Assessment Report of the Intergovernmental Panel on Climate Change [Barros, V.R., C.B. Field, D.J. Dokken, M.D. Mastrandrea, K.J. Mach, T.E. Bilir, M. Chatterjee, K.L. Ebi, Y.O. Estrada, R.C. Genova, B. Girma, E.S. Kissel, A.N. Levy, S. MacCracken, P.R. Mastrandrea, and L.L. White (eds.)]. Cambridge University Press, Cambridge, United Kingdom and New York, NY, USA, XXX pp.

Köppen W, Geiger R (1954) Klima der Erde (Climate of the Earth). Wall Map 1:16 Mill. Klett-Perthes, Gotha.

Koutsias N, Xanthopoulos G, Founda D, Xystrakis F, Nioti F, Pleniou M, Mallinis G (2013) On the relationships between forest fires and weather conditions in Greece from long-term national observations (1894-2010). International Journal of Wildland Fire 22(4) 493-507 http://dx.doi.org/10.1071/WF12003

Lung T, Lavalle C, Hiederer R, Dosio A, Bouwer LM (2013) A multi-hazard regional level impact assessment for Europe combining indicators of climatic and non-climatic change. Global Environ Change 23:522-536

Mäkelä Hm, Laapas M, Venäläinen A (2012) Long-term temporal changes in the occurrence of a high forest fire danger in Finland, Nat. Hazards Earth Syst. Sci., 12, 2591-2601, doi:10.5194/nhess-122591-2012

Moreno Mv, Chuvieco E (2013) Characterising fire regimes in Spain from fire statistics. International Journal of Wildland Fire 22, 296-305. http://dx.doi.org/10.1071/WF12061

Moriondo M, Good P, Durão R, Bindi M, Giannakopoulos C, Corte-Real J (2006) Potential impact of climate change on fire risk in the Mediterranean area. Climate Research 31, 85-95. doi: $10.3354 / \mathrm{cr} 031085$

Pellizzaro G, Ventura A, Arca B, Arca A, Duce P, Bacciu V, Spano D (2010) Estimating effects of future climate on duration of fire danger season in Sardinia. In: Viegas D.X. (Ed.), VI International Forest Fire Research Conference, Coimbra, Portugal, electronic edition.

Pereira Mg, Trigo Rm, Dacamara Cc, Pereira Jmc, Leite SM (2005) Synoptic patterns associated with large summer forest fires in Portugal. Agricultural and Forest Meteorology 129:11-25.

Salmi T, Määttä A, Anttila P, Ruoho-Airola T, Amnell T (2002) Detecting trends of annual values of atmospheric pollutants by the Mann-Kendall test and Sen's slope estimates - the Excel template application MAKESENS. (Finnish Meteorological Institute: Helsinki, Finland)

Salis M, Ager Aa, Arca B, Finney Ma, Bacciu V, Duce P, Spano D (2013) Assessing exposure of human and ecological values to wildfire in Sardinia, Italy. International Journal of Wildland Fire 22(4):549-565. http://dx.doi.org/10.1071/WF11060

Salis M, Diana G, Casula F, Farris G, Farris O, Licheri F, Musina G, Orotelli S, Peluffo L, Pirisi Am, Bacciu V, Fois C, Sirca C, Spano D (2012b) Potential effects of prescribed burning and tactical 
fires on fire risk mitigation. In: D. Spano, V. Bacciu, M. Salis, C. Sirca (ed) Modelling Fire Behaviour and Risk. Nuova Stampa Color: pp 174-180. ISBN: 978-88-904409-7-7

Snyder R, Show (1984) Converting Humidity Expressions with Computers and Calculators. Volume 21372, University of California Division of Agricultural Sciences Leaflet (University of California (System). Division of Agriculture and Natural Resources)

Spano D, Camia A, Bacciu V, Masala F, Duguy B, Trigo R, Sousa P, Venäläinen A, Mouillot F, Curt T, Moreno Jm, Zavala G, Urbieta Ir, Koutsias N, Xystrakis F (2014) Recent trends in forest fires in Mediterranean areas and associated changes in fire regimes. In: Josè M. Moreno (ED), Forest fires under climate, social and economic changes in Europe, the Mediterranean and other fire-affected areas of the world. p. 6-7, ISBN: 9788469597590.

Taylor Sw, Alexander Me (2006) Science, technology, and human factors in fire danger rating: the Canadian experience. Int. J. Wildland Fire 15, 121-135

Valese E, Anfodillo T, Rossi S, Carraro V, Deslauriers A, Carrer M, Monai M, Lemessi A, Ramon E (2008) Realizzazione di un sistema di calcolo e di spazializzazione dell'indice canadese di pericolo d'incendio boschivo FWI (Fire Weather Index) per la Regione Veneto. Forest@ 5: 176-186 [online: 2008-06-20] URL: http://www.sisef.it/forest@/.

Van Wagner Ce, Pickett TL (1987) Equations and Fortran program for the Canadian Forest Fire Weather Index System. Canadian Forestry Service, Forestry Technical Report 33, Ottawa.

Van Wagner CE (1987) Development and Structure of the Canadian Forest Fire Weather Index System. Ottawa, ON, Can. For. Serv., Tech. Rep. 35

Viegas Dx, Bovio G, Ferreira A, Nosenzo A, Sol B (1999) Comparative study of various methods of fire danger evaluation in southern Europe. Int. J. Wildland Fire 9, 235-246

Viegas Dx, Piñol J, Viegas Mt, Ogaya R (2001) Estimating live fine fuels moisture content using meteorologically-based indices. International Journal of Wildland Fire 10, 223-240

Vilen T, Fernandes P (2011) Forest Fires in Mediterranean Countries: $\mathrm{CO}_{2}$ emissions and mitigation possibilities through prescribed burning. Environmental Management, 48(3), 558-567

Wastl C, Schunk C, Leuchner M, Pezzatti G, Menzel A (2012) Recent climate change: long-term trends in meteorological forest fire danger in the Alps. Agr. Forest Meteorol., 162-163, 1-13

Zumbrunnen T, Pezzatti GB, Menendez P, Bugmann H, Burgi M, Conedera M (2011) Weather and human impacts on forest fires: 100 years of fire history in two climatic regions of Switzerland. Forest Ecology and Management 261 (12):2188-2199. - doi:10.1016/j.foreco.2010.10.009 